\title{
Diversidad de fenotípica entre cepas de Salmonella enterica serotipo Enteritidis
}

\author{
Vanessa Gornall, Patricio Retamal \\ Universidad de Chile, Facultad de Ciencias Veterinarias y Pecuarias. Santa Rosa 11.735, La Pintana. \\ Casilla 2, correo 15, La Granja. Email: pretamal@uchile.cl
}

\begin{abstract}
Resumen
En Chile y el mundo, el aumento de la prevalencia de Salmonella enterica serotipo Enteritidis en enfermedades transmitidas por alimentos, ha generado gran preocupación sanitaria y económica. La principal fuente de infección para el ser humano es el consumo de productos avícolas, aunque también se ha sugerido un rol de aves silvestres en la transmisión directa del agente, hacia personas y aves comerciales.

El objetivo de este trabajo es determinar la diversidad fenotípica ligada a virulencia de S. Enteritidis, en cepas aisladas desde aves comerciales, aves acuáticas y seres humanos en Chile.

Los fenotipos de virulencia evaluados en condiciones in vitro son la supervivencia a condiciones de acidez (pH3), a estrés oxidativo $\left(\mathrm{H}_{2} \mathrm{O}_{2} / \mathrm{NaNO}_{2}\right)$ y hambruna. Bajo estrés ácido, se ha observado que hay diferencias $(\mathrm{p} \leq 0,05)$ entre cepas de acuerdo a los porcentajes de supervivencia cuantificados a los 30 min de ensayo.

Los ensayos de estrés oxidativo $\left(\mathrm{H}_{2} \mathrm{O}_{2} / \mathrm{NaNO}_{2}\right)$, han mostrado diferencias $(\mathrm{p} \leq 0,05)$ entre cepas según los porcentajes de supervivencia cuantificados a los 30 min y $3 \mathrm{~h}$ respectivamente. Además, se ha observado diferencias $(\mathrm{p} \leq 0,05)$ entre cepas de humanos y gaviotas bajo estrés con $\mathrm{H}_{2} \mathrm{O}_{2}$.

Finalmente, bajo hambruna se ha observado diferencias $(\mathrm{p} \leq 0,05)$ entre cepas a los días 10, 20 y 30, según lo cuantificado en los porcentajes de supervivencia.

En conclusión, existe diversidad fenotípica ligada a virulencia entre cepas de $S$. Enteritidis. Sin embargo, se debe continuar evaluando si esta diversidad también se asocia al hospedero de origen, y de esta manera determinar procesos de adaptación de las bacterias a condiciones específicas de supervivencia en cada uno de ellos.
\end{abstract}

Financiamiento: Proyecto FONDECYT de iniciación Nº11110398 